\title{
O estado e a inserção ativa na economia: a estratégia de desenvolvimento econômico da China
}

Giuliano Contento de Oliveira ${ }^{1}$

Resumo: A experiência chinesa nos últimos 25 anos contradiz a tese ortodoxa de que sob contexto de globalização, resta aos países da periferia renunciar às políticas internas de desenvolvimento. O caso chinês reafirma a importância do empenho de políticas econômicas para o desenvolvimento dos países. Nesta perspectiva, o artigo discute a estratégia de desenvolvimento econômico da China no período 1978-2005, destacando a importância das reformas realizadas e a política cambial empenhada no período.

Palavras-chave: Estado; China; desenvolvimento econômico.

\section{The State and the active insertion in the economy: the strategy of economic development of China}

\begin{abstract}
The Chinese experience in the last 25 years contradicts the orthodox theory, that sustains that in the context of globalization remains the periphery countries resign the internal policies of development. The Chinese case reaffirms the importance of realizing economic policies to the development of the countries. In this perspective, the article discusses the strategy of development of China in the period 1978-2005, detaching the importance of the reforms and the exchangerate policy in the period.
\end{abstract}

Keywords: State; China; economic development.

JEL: O11, O20, E61.

\footnotetext{
1 Doutorando em Economia no IE/Unicamp. O autor agradece os comentários dos pareceristas anônimos da Revista de Economia. Evidentemente, o autor é responsável por eventuais erros e omissões contidos no artigo. E-mail: giulianoliveira@uol.com.br.
} 
DE OLIVEIRA, G. O estado e a inserção ativa na economia: a estratégia de...

\section{Introdução}

No contexto de globalização dos mercados e das finanças, instituições como FMI e Banco Mundial têm defendido a impossibilidade dos países da periferia empenharem políticas autônomas de desenvolvimento, diante dos potenciais efeitos instabilizadores causados pelo distanciamento das políticas sintonizadas com a lógica do mercado, chamadas de "market friendly". A dinâmica do ciclo de negócios de tais economias estaria subordinada tão somente a fatores exógenos, determinados pelos movimentos da economia mundial, donde as políticas internas de desenvolvimento não apenas se mostrariam neutras ou ineficazes, mas poderiam inclusive colocar em risco a estabilidade macroeconômica. Contudo, com base nesta linha de argumentação, como então explicar o sucesso da estratégia de desenvolvimento asiática?

Embora o crescimento econômico de diversos países da região observado nos últimos 25 anos tenha contado inicialmente com importantes impulsos externos positivos, com destaque à ofensiva comercial americana nos anos 1980 e a conseqüente estratégia japonesa de superar as restrições impostas pela sobrevalorização do iene no contexto do Acordo de Plaza em 1985, que implicou um processo de deslocamento de investimentos produtivos nipônicos para os $\mathrm{NICs}^{2}$ e subseqüentemente para os países da ASEAN-4 ${ }^{3}$ e China, as políticas econômicas ativas empenhadas por diversos países asiáticos certamente concorreram para potencializar os efeitos macroeconômicos positivos deste processo.

Neste particular, dentre todas as experiências asiáticas de desenvolvimento, chama especial atenção o caso da China, não apenas pelas taxas de crescimento elevadas e ininterruptas e as conseqüentes transformações econômicas e sociais ocorridas nos últimos 25 anos, mas também e notadamente por revelar sob maior grau de nitidez a importância das políticas internas no desenvolvimento das nações.

$\mathrm{O}$ artigo discute a experiência chinesa de desenvolvimento, chamando particular atenção ao processo de modernização realizado desde o final dos anos 70, que concorreu para estruturar um ambiente favorável às decisões de inversão, bem como à política cambial e à inserção externa diferenciada do país, vetores que têm transformado a China numa grande potência internacional. Sustenta-se, neste sentido, que o manejo adequado dos instrumentos de política econômica se apresenta enquanto elemento decisivo no processo de superação da condição de subdesenvolvimento, havendo assim espaço para o empenho de políticas

\footnotetext{
2 Newly Industrialized Countries. Estes países correspondem aos chamados 4 tigres asiáticos, a saber: Hong Kong, Cingapura, Coréia do Sul e Taiwan (Formosa).

3 Correspondem aos seguintes países: Tailândia, Indonésia, Malásia e Filipinas.
} 
nacionais de desenvolvimento mesmo sob contexto de "tirania dos mercados".

O artigo está dividido em quatro itens, não incluindo esta introdução. A seguir, são discutidas, em seus aspectos mais marcantes, as reformas econômicas realizadas na China a partir do final dos anos 70, relacionando-as com o sucesso econômico dos últimos anos e com a inserção externa diferenciada da economia chinesa. No segundo item, discorrese sobre as políticas de subvalorização e administração da taxa de câmbio empenhadas pelo governo chinês, que têm permitido ao país a obtenção de elevados superávits em conta-corrente do balanço de pagamentos e, ao cabo, a sustentação de uma blindagem externa que respalda e reforça a inserção soberana da China na economia mundial. Posteriormente, a partir de indicadores econômicos selecionados, analisa-se a trajetória da economia chinesa desde os anos 1980. Finalmente, são registradas as conclusões.

\section{Reformas, "socialismo de mercado" e inserção externa particular}

O conjunto de reformas empenhado na China a partir de 1978 buscava superar a organização econômica de planejamento centralizado, incorporando gradualmente os mecanismos de mercado e empenhando uma política de abertura, sem a abdicação da propriedade e dos mecanismos de planejamento do Estado. Tais reformas implicaram transformações históricas de significativa magnitude, que atuaram no sentido de deslocar a economia chinesa de uma economia planificada para uma economia de mercado com características peculiares; de uma economia agrícola tradicional para uma economia industrializada; e têm permitido ao país a condição de um ator importante no cenário mundial, conforme será discutido (Oliveira 2005; He 2003).

No entanto, como bem observa Oliveira (2005), embora as reformas implementadas por Deng Xiaoping a partir do final dos anos 1970 sejam consideradas um marco na explicação do sucesso econômico da China nos últimos 25 anos, os impactos da Revolução de 1949, quando Mao Zedong fundou a República Popular da China (RPC), foram fundamentais para o desempenho econômico do país a partir dos anos 1980, pois permitiram a estruturação de uma sociedade mais igualitária, o provimento de infra-estrutura urbana e rural e a criação de uma burocracia formada a partir de critérios meritocráticos, condições que viabilizaram e potencializaram os efeitos das reformas a partir do último quartel do século XX.

Portanto, mais do que revolucionárias, as mudanças ocorridas na China a partir de Deng Xiaoping devem ser interpretadas sob uma perspectiva 
DE OLIVEIRA, G. O estado e a inserção ativa na economia: a estratégia de...

evolucionária, depois das tentativas frustradas de reorientação econômica e social do país. Comparando o gradualismo chinês com o caráter apressado das reformas orientadas para o mercado observado em diversos países do Leste Europeu e na ex-República Soviética, cujos erros e acertos serviram de referência para a modernização da China, Hussain (1994: 12) afirma que:

\begin{abstract}
Em contraste, os Chineses são persistentes com sua "longa marcha" em direção à economia de mercado, com sua abordagem gradual de reformas, embora às vezes radical, embora ainda possuam características da antiga economia de planejamento centralizado, tais como planejamento da produção, embora seletivo, e a propriedade estatal de empresas médias e grandes. [tradução do autor]
\end{abstract}

O programa de modernização da economia chinesa contemplou os seguintes setores: agricultura, indústria, ciência e tecnologia e forças armadas (Sydow 2004). Conforme registrado por Medeiros (1999a: 10405), a estratégia de desenvolvimento chinesa baseava-se na aplicação das experiências internacionais bem-sucedidas à realidade do país, a partir de um planejamento que buscava: a) reformar a utilização da terra; b) aumentar as exportações e proteger o mercado interno; c) formar grandes grupos estatais competitivos internacionalmente; d) reformar as empresas estatais, adequando-as ao novo ambiente econômico; e) promover as empresas coletivas de vilas e municípios; e f) configurar uma economia do tipo mista, com preços regulados, controlados e de mercado, estratégia da qual decorre a expressão "economia socialista de mercado" ou simplesmente "socialismo de mercado".

No âmbito agrícola, o processo de modernização correspondeu ao período compreendido entre o final dos anos 1970 e o início dos 1980. Introduziu-se o sistema de responsabilidade ou de contrato familiar na área rural, já adotado em 1978 secretamente por várias aldeias na província de Anhui, em substituição à organização coletiva da produção estruturada no período do Grande Salto à Frente (1958-61). O sistema se difundiu rapidamente e em 1983 já atingia 93\% das áreas rurais. O Estado cedia a terra e o produtor rural o pagava com quotas da produção, decrescentes ao longo do tempo, a partir de contrato de arrendamento de longo prazo estabelecido com a comuna (He 2003; Sydow 2004)4.

A autonomia do camponês quanto ao escoamento da produção que excedia a parcela devida ao Estado, bem como sua subsistência, implicou um forte ganho de produtividade no meio rural, aumentando a produção de alimentos e gerando emprego e renda (He 2003; Sydow 2004).

4 Atualmente, apenas alguns produtos permanecem submetidos a quotas governamentais, considerados estratégicos pelo Estado (Sydow 2004). 
De acordo com HE (2003: 46), dado o sucesso alcançado, "[...] as empresas de comunas e aldeias proliferaram e se tornaram uma força decisiva para o crescimento da China.". No mais, por um lado estas empresas concorreram para acomodar a demanda suplementar por bens de consumo criada pelos vultosos investimentos estatais no setor de bens de produção, bem como para viabilizar o processo de substituição de importações a partir da segunda metade dos anos 1980, e, por outro, para estimular a demanda por manufaturas e, ao cabo, o desenvolvimento industrial, a partir da geração de renda no meio rural (Medeiros 1999a; Wolff e Soto 2005).

Já na esfera industrial, buscou-se a partir de uma política seletiva de importações incorporar tecnologia e bens de capital para dar curso ao processo modernização e ganho de competitividade do setor. Esta estratégia apenas poderia ser viabilizada a partir de iniciativas concomitantes voltadas à ampliação da capacidade de geração de divisas, de sorte a permitir a superação da pressão oriunda do aumento das importações, especialmente de bens de produção.

É nesta perspectiva que deve ser entendida a criação de Zonas Econômicas Especiais (ZEE) a partir de 1982, localizadas nas regiões costeiras próximas aos mercados asiáticos mais dinâmicos, como Japão, Hong Kong e Taiwan, abertas ao capital estrangeiro e voltadas à produção de bens para o mercado externo, onde as empresas contavam com benefícios fiscais e liberdade cambial, facilidades logísticas e portuárias, além de autonomia administrativa e financiamentos concedidos pelo Estado. O projeto de modernização era híbrido: mantinha-se a propriedade pública das empresas e, ao mesmo tempo, estimulava-se a difusão das empresas não estatais, como as Empresas de Vilas e Municípios (EVM) e joint ventures (Sydow 2004; Cesarin 2005).

A iniciativa de implementar as ZEEs nas regiões costeiras atuou no sentido de potencializar os impulsos favoráveis provenientes da ofensiva comercial americana levada a cabo nos anos 1980 contra o Japão, da qual resultou a "endaka" (1985-95) . A valorização do iene provocou um forte deslocamento do capital produtivo japonês para os NICs e posteriormente para os países da ASIAN-4 e para a China. A extensão da

\footnotetext{
5 A “endaka" (1985-95) consistiu na valorização substantiva do iene frente ao dólar ocorrida na esteira do Acordo de Plaza em 1985. Este, por seu turno, consistiu numa resposta dos Estados Unidos às políticas tidas como protecionistas realizadas por outros países, com especial destaque ao Japão, que surtiam efeitos negativos sobre a indústria americana. Buscava-se, com isso, reverter a brutal valorização do dólar frente ao iene. A valorização do iene, segundo Belluzzo (2006: 29), deslocou as exportações japonesas para a área de predominância da moeda americana, por um lado, e causou fortes prejuízos para o sistema financeiro japonês, por outro, dada a parcela da carteira de ativos dos bancos, corretoras e seguradoras atrelada ao dólar. Não menos importante, a "endaka" provocou um forte deslocamento da indústria japonesa para os países da região, entre os quais a própria China, de sorte a contornar os efeitos negativos sobre a competitividade da indústria japonesa causados pela valorização do iene.
} 
DE OLIVEIRA, G. O estado e a inserção ativa na economia: a estratégia de...

ofensiva dos EUA aos tigres asiáticos, ao implicar um movimento de forte valorização de suas moedas ante o dólar no final dos anos 1980, provocou o deslocamento de investimentos produtivos não apenas do Japão, mas agora também dos 4 "tigres", especialmente de Hong Kong para a China e os países da ASIAN-4 (Medeiros 1997).

À luz da hipótese dos "gansos voadores" tal qual reformulada e proposta por Medeiros (1997: 327-28), pode-se considerar que a China, na condição de "ganso retardatário", passa a atuar e tirar proveito das brechas deixadas pelos "gansos líderes" a partir de meados da década de 1980, particularmente Japão e Hong Kong. Nestes termos, tais países passam a delegar à China as etapas de produção com maiores vantagens competitivas, condição que conjugada aos benefícios das ZEEs, permitiu a utilização do país enquanto região de processamento e escoamento de parcela importante da produção voltada ao mercado externo de diversos países do sudeste asiático. Já em 1992, 45\% das exportações de Hong Kong eram originadas da China. A abertura deu curso a um processo de internalização de know-how, condição que conjugada a uma política industrial ativa que buscou potencializar os encadeamentos interindustriais para frente e para trás a partir das empresas ingressantes, permitiu à China alçar degraus cada vez maiores em termos de processamento de bens com maior densidade tecnológica, maior geração de valor adicionado. Isto porque, conforme assinalado por Medeiros (1997: 328):

[...] uma vez adquirida maior maturidade industrial - menores efeitos expansivos internos, maiores pressões sobre o balanço de pagamentos o deslocamento tecnológico do ganso líder estimula a introdução de novos setores/técnicas - tanto mais rápida quanto maior for a ofensiva de catching-up - abrindo espaço para o ganso subseqüente internalizar as atividades de menor densidade tecnológica e repetir a mesma dinâmica.

As ZEEs ilustram como o manejo dos instrumentos de política econômica à luz de um objetivo de transformação da realidade, ao invés de adaptação, pode contribuir para potencializar eventuais impulsos externos positivos, ou mesmo para criar condições endógenas de dinamização do ciclo de negócios. A resposta da China ao novo ambiente externo ensejado pela ofensiva comercial americana contra o Japão e, posteriormente, contra os NICs, mostra que as estratégias nacionais de desenvolvimento se apresentam essenciais no processo de criação de forças endógenas que concorreram para a superação da condição de subdesenvolvimento. No essencial, as ZEEs constituíram um importantíssimo diferencial para a China, diante da nova configuração regional de 
comércio que passou a prevalecer na Ásia a partir de meados dos anos 1980.

Estas transformações provocaram um processo concomitante de dinamização do mercado interno, à medida que parcela crescente da renda gerada pelas atividades exportadoras passava a gravitar em âmbito doméstico, o que introduzia um vetor adicional de estímulo às decisões de inversão dos empresários locais e estrangeiros. É por conta disso que Medeiros (1999a: 107) qualifica a política econômica chinesa de, ao mesmo tempo, indutora do "... desenvolvimento do mercado interno e da promoção de exportações." O ingresso de investimentos estrangeiros possibilitado pela abertura, coadunado ao processo de modernização das empresas estatais, permitiu a consolidação da estratégia do governo chinês de criação de uma economia voltada à tecnologia, que nas palavras de Cesarin (2005: 8):

[...] consolida um enfoque de política industrial que privilegia a evolução desde indústrias “mão de obra intensivas" até "capital intensivas" com capacidade de responder de forma rápida aos estímulos externos decorrentes da globalização dos mercados, da abertura, da desregulação da economia Chinesa e das oportunidades criadas pelos novos "mercados regionais. [tradução do autor]

Esta estratégia mostrou-se potencializada pela criação das Zonas de Desenvolvimento Econômico e Tecnológico (ZDET), que conjugadas às ZEEs, deu curso a um processo de indução tecnológica a partir de parcerias com diversos países da região. Buscava-se, com isto, atrair investimentos externos em tecnologia para o desenvolvimento dos setores de infra-estrutura econômica, notadamente energia e transportes. A modernização do setor de ciência e tecnologia contou e continua a contar com uma política do governo chinês de estímulo à qualificação e especialização de estudantes no exterior (Sydow 2004; Acioly 2005).

O volume e a composição dos Investimentos Estrangeiros Diretos (IED) recebidos notadamente a partir do início dos anos 1990, momento a partir do qual se estrutura um marco regulatório mais estruturado, por um lado, e se faz sentir de forma mais intensa a reconfiguração do comércio asiático ensejado pela ofensiva americana contra o Japão e os "tigres", por outro, revelam o êxito da estratégia de constituição das ZEEs e das ZDET.

A entrada de IED passa de US\$ 3,49 bilhões em 1990, para US\$ 60,63 bilhões em 2004, pouco abaixo do fluxo recebido por toda a América Latina e Caribe no período, US\$ 67,53 bilhões. Considerando os dados de estoque, no interregno 1980-2004 o país recebeu US\$245,47 bilhões de IED. Apenas no intento de estabelecer uma base de 
DE OLIVEIRA, G. O estado e a inserção ativa na economia: a estratégia de...

comparação, em 2004 ingressou no Brasil sob a forma de IED US\$ 18,17 bilhões, enquanto o acumulado no interregno 1980-2004 totalizou US\$ 150,96 bilhões ${ }^{6}$ (Unctad 2005b).

Contudo, diferentemente do Brasil, na China apenas parcela marginal da entrada de IED se deu sob a forma de operações de fusões e aquisições transfronteiras e de privatizações. No mais, mostrou-se praticamente nulo o ingresso de IED no sistema financeiro, tendo em vista as restrições impostas pelo governo em relação ao setor (Acioly 2005).

É importante assinalar, pois, que a intensificação do ingresso de IED a partir do início dos anos 1990 se mostrou como expediente fundamental no processo de mudança do padrão de financiamento externo da economia chinesa. Isto porque nos anos 1980, depois das exportações, a captação de empréstimos dos bancos e dos credores oficiais correspondia à segunda forma de obtenção de divisas. Nos anos 1990 este quadro é modificado, com os IEDs ocupando o lugar que os empréstimos e financiamentos ocuparam na década anterior (Medeiros 1999b).

A partir de um marco regulatório que dispunha de mecanismos que exigiam contrapartidas das empresas estrangeiras participantes das ZEEs, a mudança do padrão de financiamento externo, além de viabilizar a obtenção de divisas sob bases mais sustentáveis, permitiu a consolidação do tripé: a) aumento da participação da China no comércio internacional; b) estímulo ao acesso às fontes externas de capital e tecnologia avançada; e c) introdução de modernas técnicas administrativas e de gestão nas empresas chinesas (Acioly 2005).

Já com a modernização das Forças Armadas, intentava-se alçar a capacidade do país de exercer o seu papel de potência econômica e militar regional, com a capacidade bélica funcionando enquanto expediente de barganha política e comercial junto aos demais países do globo. No mais, embora não menos importante, a modernização do Exército de Libertação Popular constituía quesito singular na estratégia de desenvolvimento traçada por Deng Xiaoping, diante das disputas regionais ainda não resolvidas, embora concebida por alguns autores enquanto simples intro-

6 De acordo com as notas metodológicas apresentadas em UNCTAD (2005b: 299), para a maioria dos países os dados de estoque dos IEDs foram calculados ou mediante a soma dos dados de fluxo ao longo do período compreendido; ou adicionando ou subtraindo fluxos de um dado de estoque obtido em um determinado período a partir de fontes nacionais oficiais; ou mediante as séries de dados do FMI sobre ativos e passivos de investimentos diretos; ou usando, em alguns poucos casos, os dados de estoque das principais economias como proxy. De um modo geral, portanto, os dados de estoque ora apresentados referem-se aos dados de fluxo acumulados no interregno considerado. 
dução de técnicas eficientes de gestão e delegação das empresas estatais à iniciativa privada7. De acordo com Sydow (2004: 40, grifo nosso):

\begin{abstract}
Ao modernizar as forças armadas, a China se capacitava para poder exercer seu papel de potência econômica regional na Ásia, região onde ainda há alguns conflitos não resolvidos, principalmente no Mar do Sul da China. São principalmente disputas territoriais ainda não resolvidas como as ilhas Paracels e Spratly, reclamadas pela China, Vietnã e Filipinas; as ilhas Senkaku ao nordeste de Taiwan, reclamadas pela China, pelo Japão e Taiwan, que a China considera como seu território. Por trás destas disputas estão as reservas de petróleo, óleo e gás natural, além de sua posição estratégica para as rotas de navegação principalmente do Japão.
\end{abstract}

Mas o sucesso econômico chinês observado especialmente desde o início da década de 1990 não pode ser atribuído apenas aos impactos positivos gerados pelas reformas implementadas a partir de Deng Xiaoping. Isto porque a construção de um ambiente macroeconômico favorável às decisões de investimento, obtida a partir do manejo eficiente dos instrumentos de política econômica, desempenhou papel decisivo no crescimento dos níveis de renda e emprego do país no período considerado (Flassbeck 2005).

Neste particular, um traço marcante da política macroeconômica chinesa tem sido indiscutivelmente a administração cuidadosa da taxa de câmbio e a sua manutenção, notadamente a partir de 1994, num patamar subserviente ao crescimento econômico e a uma inserção externa soberana, o que permitiu à China maximizar o poder de transformação das reformas implementadas. Em invés de uma inserção externa ancorada na captação de capitais de curto prazo, pela conta de capital do balanço de pagamentos (capital-account), o governo chinês optou por uma inserção balizada na exportação em larga escala de produtos manufaturados com graus crescentes de densidade tecnológica a preços altamente competitivos, pela via do comércio internacional (tradeaccount). Esta forma de inserção tornou o país praticamente imune às instabilidades da economia mundial, além de ter permitido relevantes graus de liberdade no manejo da política econômica.

\title{
2. Yuan fraco, economia forte
}

A política cambial chinesa tem sido apontada por vários autores como elemento fundamental para a explicação do sucesso econômico do país

7 Sobre esta interpretação, aqui considerada insuficiente para explicar o propósito da modernização das forças armadas na China, ver Wolff y Soto (2005: 64-66). 
DE OLIVEIRA, G. O estado e a inserção ativa na economia: a estratégia de...

nos últimos anos ${ }^{8}$. Após instituir as ZEEs, as autoridades econômicas locais desvalorizaram em 36,24\% o Yuan Renminbi (RMB) ante o dólar durante 1984 e estabeleceram um mercado dual de câmbio, a saber: o oficial, assentado no regime de flutuação, e o mercado de swaps com acesso exclusivo às tradings e às empresas participantes das ZEEs, em que o preço da moeda estrangeira se apresentava mais favorável aos exportadores. Ficaram assim estabelecidas as condições macroeconômicas básicas para a atração de investimentos produtivos para a região, a partir dos quais se constituiu uma vigorosa estrutura de geração de divisas para o país (Medeiros 1999a).

Flassbeck (2005: 11-13) desqualifica a política cambial executada na China durante os anos 1980, considerando que, de um lado, não se mostrou suficiente para estabelecer um patamar competitivo internacionalmente para o RMB, haja vista o movimento de valorização da taxa de câmbio oficial real efetiva observado no interregno 1987-94, e, de outro, contribuiu para as condições de volatilidade monetária e de risco de desestabilização da moeda, diante das desvalorizações cambiais expressivas e periódicas realizadas no período (Figuras 1 e 2).

É verdade que em alguns anos da década de 1980 a China registrou déficit em transações correntes do balanço de pagamentos (Figura 3), o que poderia indicar a prática de uma política cambial equivocada. Contudo, o manejo da taxa de câmbio pelo governo chinês neste período refletia uma tentativa de driblar as restrições de balanço de pagamentos

FIGURA 1- INFLAÇÃO E TAXA DE JUROS REAL NA CHINA (1980-2005)

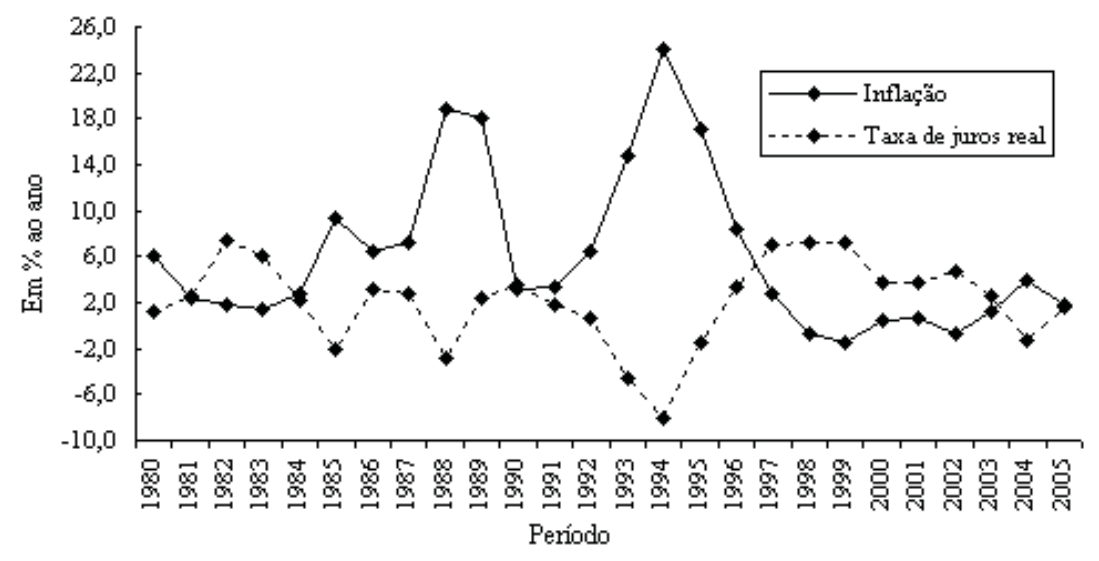

Fonte: Database IMF (www.imf.org).

8 Ver Cunha e Biancareli (2005); Flassbeck (2005); Medeiros (1997; 1999a; 1999b; 2004; 2005) e Vieira (2006). 
FIGURA 2- TAXA DE CÂMBIO NOMINAL NA CHINA (1980-2005)

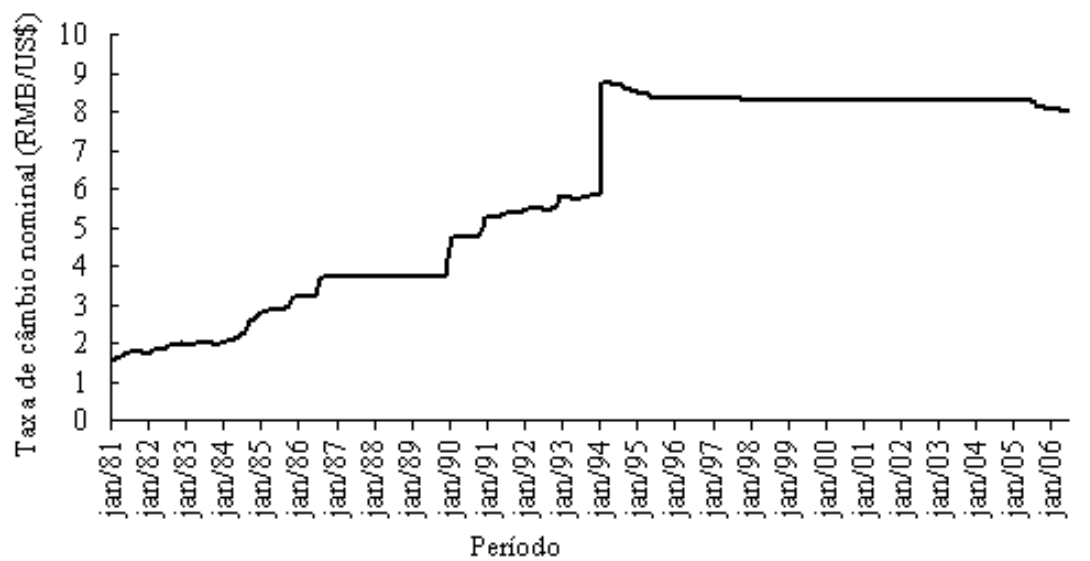

Fonte: Database IMF (www.imf.org).

\section{FIGURA 3- SALDO EM TRANSAÇÕES CORRENTES DO BALANÇO DE PAGAMENTOS EM \% DO PIB NA CHINA E NOS EUA (1980-2005)}

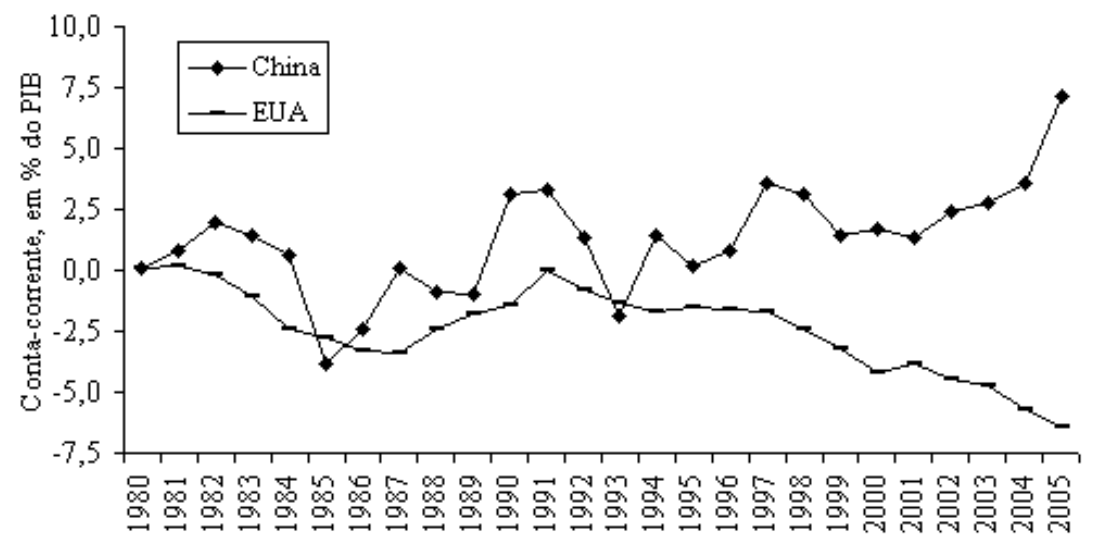

Fonte: Database IMF (www.imf.org).

inexoravelmente envolvidas num processo de industrialização por substituição de importações (ISI). Por ainda não contar com uma elevada e sofisticada capacidade exportadora, tal qual observada no período mais recente, a manutenção da taxa de câmbio num patamar subvalorizado sob um mercado cambial unificado certamente atuaria no sentido de sobre-penalizar as contas externas do país e, assim, obstaculizar o processo de complexificação industrial almejado e já em curso deste então.

Mostra-se complicado, então, estabelecer uma comparação entre a política cambial executada nos anos 1980 e a praticada a partir de 1994, 
como faz Flassbeck (2005), haja vista as distintas circunstâncias políticas e econômicas de cada período. Se por um lado a política cambial praticada na China nos anos 1980 não permitiu a construção de um ambiente macroeconômico estável, tendo em vista os impactos das desvalorizações sobre as condições monetárias e as expectativas dos agentes (Figuras 1 e 2), por outro revelou a capacidade do governo em adaptar os instrumentos de política econômica às necessidades exigidas pelas circunstâncias do momento. A opção por um mercado dual de câmbio, com a taxa de swap mais depreciada do que a praticada no mercado oficial, juntamente com uma hierarquia de prioridades da pauta de importações estabelecida a partir de um sistema de taxas múltiplas de câmbio, buscava ampliar a capacidade de obtenção de divisas, de um lado, e racionalizar a sua utilização, de outro.

No mais, a taxa de câmbio real durante os anos 1980, considerando a taxa média anual de câmbio do RMB ante o dólar e descontando o diferencial de inflação interna e americana (externa), apresentou uma clara trajetória de depreciação (Figura 4). No interregno 1980-1990, tomando-se por base o índice da taxa de câmbio real com base 1990=100, a desvalorização real do RMB alcançou 66,45\%. Na comparação com a taxa média do ano anterior, apenas em 1988 registrou-se apreciação real do RMB frente ao dólar. E embora o comportamento do índice da taxa de câmbio real efetiva nos anos 1980 revele forte apreciação do $\mathrm{RMB}$, até o fim da década o índice se manteve acima do ano base de 1990=100, com exceção de 1988, quando o índice ficou em 97,31 (Figura 4). Portanto, conquanto as desvalorizações nominais e reais periódicas da taxa de câmbio tenham prejudicado o controle da inflação nos anos 1980, elas concorreram para permitir a construção das bases de um ajustamento de caráter estrutural do Balanço de Pagamento chinês, cujos efeitos se fariam sentir de forma intensa a partir da segunda metade da década de 1990 (Figura 3).

A partir de 1994 o governo chinês inicia uma nova fase no manejo da política cambial. O People's Bank of China realizou uma maxidesvalorização do RMB de 49,83\% entre dez.93/jan.94, que passou de RMB 5,82, para RMB 8,72 por dólar; unificou o mercado de câmbio, em substituição ao mercado dual; e adotou um regime de bandas cambiais, com o RMB podendo flutuar num intervalo estabelecido pelas autoridades econômicas. Tais medidas surtiram efeito instantâneo sobre as contas externas do país: a conta-corrente do balanço de pagamentos saiu de um déficit de 1,9\% em 1993 e atingiu um superávit de 1,4\% em 1994, período a partir do qual se inicia a obtenção de uma série de saldos positivos em transações correntes.

Embora a depreciação nominal tenha sido parcialmente compensada pelo diferencial de inflação interna e americana em 1994, tendo em 

FIGURA 4- TAXA DE CÂMBIO REAL E TAXA DE CÂMBIO REAL EFETIVA NA
CHINA (1981-2005)

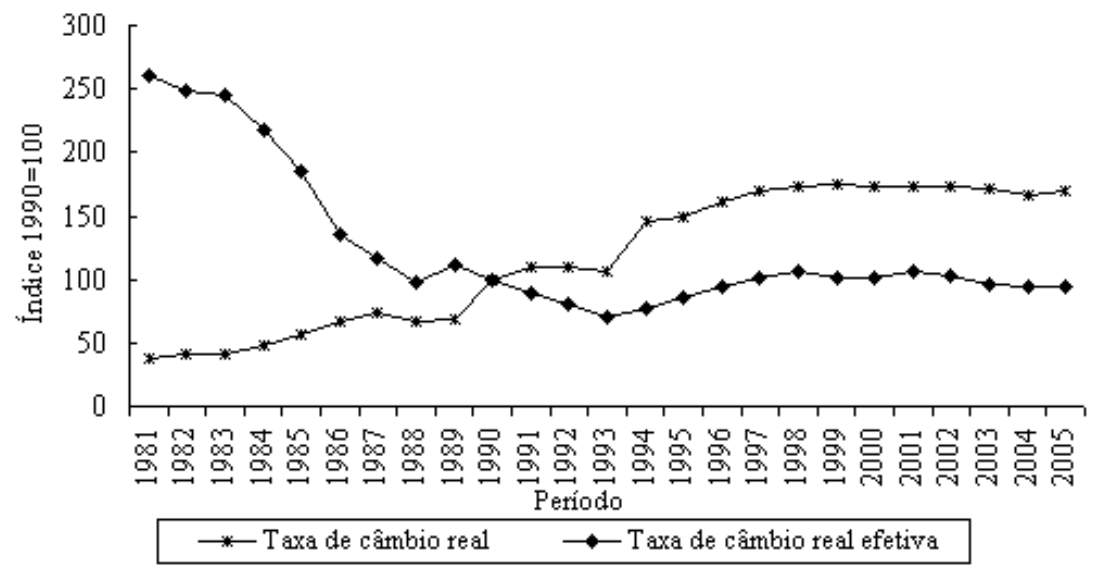

Fonte: Database IMF (www.imf.org) e World Bank (2007). Taxa de câmbio real calculada pelo autor, considerando a taxa de câmbio nominal média anual, a partir de dados mensais, e o diferencial de inflação da China e dos EUA. Índice base $1990=100$.

vista o repique inflacionário causado pela medida, observou-se uma mudança do patamar da taxa de câmbio real na China a partir de 1995 (Figura 4). Considerando a taxa de câmbio real efetiva, medida mais eficiente do grau de competitividade internacional de uma moeda, a partir de 1994 observa-se uma inversão da trajetória de valorização do RMB iniciada em 1980 e passa a se registrar uma clara trajetória de desvalorização da taxa de câmbio real efetiva chinesa (Figura 4).

Entre 1994-96, sob bandas relativamente largas de flutuação, o RMB sofreu uma valorização de 4,5\%, passando de RMB 8,72, para RMB 8,33 por dólar. Embora o governo chinês tenha optado por não desvalorizar o yuan em meio à crise asiática em 1997, condição que contribuiu fortemente para que os países da região se recuperassem - ao evitar uma corrida cambial e afirmar o RMB enquanto moeda-chave no comércio regional - e, adicionalmente, tenha atuado na direção de deslocar as empresas americanas que operavam na ASEAN- $4^{9}$ para o país, o governo Chinês decidiu estreitar a banda de flutuação do RMB frente ao dólar para $0,4 \%$, com a taxa de câmbio em torno de RMB 8,28 por US\$1. Em novembro de 2000 limitou-se ainda mais a banda de flutuação, para o,01\% em torno de RMB 8,277 por dólar, o que significou a assunção de um regime de câmbio fixo "na prática", mantendo-se esta estratégia até meados de 2005 (Flassbeck 2005; Medeiros 2005).

9 Isto porque como as moedas destes países eram atreladas ao dólar americano, elas acompanharam a valorização do dólar frente ao yen japonês, que foi desvalorizado cerca de 30\% entre 1996-98. Para uma análise mais detida deste processo, ver Medeiros (2005). 
DE OLIVEIRA, G. O estado e a inserção ativa na economia: a estratégia de...

Com uma taxa de câmbio baixa e estável, que concorreu para estimular as exportações e suprimir os riscos envolvidos nas decisões de investimento, respectivamente, e a prática de uma taxa de juros baixa sem o comprometimento do controle inflacionário, condição permitida pela execução de políticas auxiliares de controle inflacionário - como o controle de preços e salários -, a China conseguiu construir um ambiente macroeconômico altamente propício às decisões de inversão, componente dinamizador do excepcional desempenho de sua economia (Figura 5).

Como mostrado na Figura 1, mesmo depois de ter sido negativa entre 1993-95 por conta da inflação superior a dois dígitos, a taxa de juros real permaneceu num patamar altamente favorável ao investimento. A formação bruta de capital fixo, partindo de uma base 100 em 1994, atingiu patamar superior a $240 \mathrm{em} \mathrm{2003,} \mathrm{crescimento} \mathrm{cujos} \mathrm{reflexos} \mathrm{se}$ fizeram sentir de forma pronunciada sobre o nível de consumo interno, que passou de um índice de 100, para aproximadamente 210 no interregno considerado (Tabela 1$)^{10}$. O resultado deste processo foi um crescimento médio de 9,45\% no período 1994-2003. Cumpre salientar, ainda, que o comportamento destas variáveis econômicas agregadas na China guarda grande similitude com o observado nos demais países da região que alçaram à condição de nações desenvolvidas em seus respectivos períodos de ascensão (catching-up), como Japão e Coréia. Nos termos de Flassbeck (2005: 17):

[...] a depreciação nominal da taxa de câmbio em combinação com a reação não-inflacionária de outros custos variáveis [...] constituiu uma inovação para os exportadores chineses e para as firmas estrangeiras que estavam produzindo ou planejavam produzir na China. $\mathrm{Na}$ China, a observância de condições macroeconômicas estáveis e prócrescimento, combinada com um mercado doméstico em expansão num ambiente não inflacionário, ofereceu aos investidores domésticos e internacionais um contexto de expectativas de lucro estável necessário para o investimento em capital fixo em larga escala. [tradução do autor]

Contudo, a política cambial praticada na China, utilizada enquanto instrumento subjugado ao rol das políticas nacionais de desenvolvimento, ao invés de simples instrumento de desinflação ${ }^{11}$, passou a ser crescentemente questionada pelas autoridades dos EUA, ante a trajetória de forte alta do déficit em transações correntes do balanço de pagamentos da economia americana, que passou de cerca de 1,5\% do PIB no

10 Cumpre salientar que os níveis de investimento e consumo também cresceram significativamente no decorrer dos anos 1980, o que resultou na forte expansão da economia chinesa no período.

11 Conforme revelou a experiência de muitos países latino-americanos nos anos 1990 e 2000. 
DE OLIVEIRA, G. O estado e a inserção ativa na economia: a estratégia de...

TABELA 1- INDICADORES MACROECONÔMICOS SELECIONADOS: CHINA, JAPÃO E CORÉIA

\begin{tabular}{|c|c|c|c|c|c|c|c|c|c|c|}
\hline \multirow{2}{*}{$\begin{array}{l}\text { Indicadores - períodos de catching-up } \\
\text { Crescimento Econômico } \\
\text { (período inicial = 100) }\end{array}$} & \multicolumn{10}{|c|}{ Anos } \\
\hline & $1^{o}$ & $2^{\mathrm{O}}$ & $3^{o}$ & $4^{o}$ & $5^{\mathrm{o}}$ & $6^{0}$ & $7^{0}$ & $8^{\circ}$ & $9^{0}$ & $10^{\circ}$ \\
\hline China 81-90 & 100,0 & 109,1 & 121,0 & 139,4 & 158,2 & 172,1 & 192,1 & 213,8 & 222,6 & 231,0 \\
\hline China 94-03 & 100,0 & 110,9 & 122,0 & 133,3 & 143,7 & 154,7 & 167,7 & 181,6 & 198,1 & 217,9 \\
\hline Japão 61-70 & 100,0 & 108,9 & 118,1 & 131,9 & 139,6 & 154,5 & 171,6 & 193,7 & 217,9 & 241,2 \\
\hline Coréia 68-77 & 100,0 & 114,1 & 123,6 & 133,8 & 139,8 & 156,6 & 167,9 & 177,8 & 196,6 & 216,3 \\
\hline Coréia 83-92 & 100,0 & 108,1 & 115,5 & 127,7 & 141,9 & 157,0 & 167,6 & 182,9 & 200,1 & 211,9 \\
\hline \multicolumn{11}{|l|}{$\begin{array}{l}\text { Crescimento do consumo final } \\
\text { (período inicial }=100 \text { ) }\end{array}$} \\
\hline China 81-90 & 100,0 & 106,5 & 123,6 & 147,7 & 177,6 & 193,5 & 210,5 & 241,5 & 255,4 & 253,7 \\
\hline China 94-03 & 100,0 & 108,4 & 120,9 & 137,6 & 148,5 & 161,7 & 177,1 & 189,6 & 200,9 & 208,8 \\
\hline Japão 61-70 & 100,0 & 108,5 & 117,3 & 128,8 & 136,2 & 149,1 & 162,4 & 177,1 & 195,0 & 209,1 \\
\hline Coréia 68-77 & 100,0 & 116,7 & 128,2 & 138,5 & 144,0 & 156,1 & 163,9 & 174,7 & 188,0 & 199,0 \\
\hline Coréia 83-92 & 100,0 & 105,7 & 112,8 & 123,2 & 133,1 & 145,0 & 157,8 & 168,8 & 183,5 & 196,6 \\
\hline \multicolumn{11}{|l|}{$\begin{array}{l}\text { Crescimento da Formação Bruta de } \\
\text { Capital Fixo (período inicial = 100) }\end{array}$} \\
\hline China 81-90 & 100,0 & 111,3 & 125,8 & 147,4 & 171,2 & 187,4 & 214,3 & 234,8 & 201,9 & 207,7 \\
\hline China 94-03 & 100,0 & 110,5 & 122,1 & 124,7 & 138,5 & 153,7 & 167,1 & 181,5 & 206,5 & 241,7 \\
\hline Japão 61-70 & 100,0 & 114,1 & 127,8 & 147,8 & 154,6 & 176,4 & 208,3 & 250,9 & 298,3 & 348,6 \\
\hline Coréia 68-77 & 100,0 & 124,8 & 126,0 & 131,9 & 134,1 & 169,3 & 193,2 & 210,5 & 254,2 & 330,9 \\
\hline Coréia 83-92 & 100,0 & 110,9 & 116,7 & 130,2 & 153,7 & 174,6 & 202,6 & 254,1 & 290,8 & 292,4 \\
\hline
\end{tabular}

Fonte: World Bank (2007). Cálculo do autor. Períodos de catching-up sugeridos por Flassbeck (2005).

início dos anos 1990 para aproximadamente 6,5\% do PIB em 2005, contra um superávit em conta corrente de $7,2 \%$ do PIB em 2005 na China $^{12}$ (Figura 3). Os déficits dos EUA, segundo o argumento oficial americano, decorrem da política de subvalorização do RMB frente ao dólar, que por seu turno atribui uma injusta e espúria vantagem dos chineses no âmbito do comércio internacional. ${ }^{13}$ (Cunha et al. 2006; FSP 2005a)

É interessante notar a similitude entre a ofensiva americana contra a política cambial chinesa e a ofensiva comercial americana levada a cabo nos anos 1980 contra o Japão, da qual resultou a "endaka". Esta postura dos Estados Unidos nada mais reflete, em essência, que a hierarquia e assimetria prevalecente no Sistema Monetário Internacional contemporâneo sob a égide do padrão dólar-flexível, erigido após a supressão dos acordos de Bretton Woods no início dos anos 1970 (Oliveira et al. 2007). Diferentemente do Japão, contudo, a China tem realizado um movimento bastante gradual e adaptativo de sua taxa de câmbio,

12 De acordo com as estimativas do FMI (2007), depois de ter alcançado 9,1\% do PIB em 2006, o superávit da China em transações correntes do Balanço de Pagamentos deverá alcançar 10\% em 2007 e 10,5\% em 2008.

13 É importante ressaltar, no entanto, que parcela das exportações chinesas para os EUA provém de empresas americanas que operam na China, atraídas pelos baixos custos de produção. O outourcing introduz, portanto, um componente estrutural no déficit em conta-corrente do balanço de pagamentos americano, contra o qual a valorização do yuan frente ao dólar se apresenta neutra. 
DE OLIVEIRA, G. O estado e a inserção ativa na economia: a estratégia de...

depois de o Bank's People of China substituir o regime de câmbio fixo pelo de "flutuação administrada" em de julho de 2005. Depois de uma valorização do yuan de 2,1\% em 21.07.2005, o RMB passou a poder flutuar em torno de um intervalo bastante estreito - o,3\% ao dia em relação ao dólar e $1,5 \%$ ao dia para as demais moedas que compõe a referida cesta de moedas, cuja composição não foi revelada quando do anúncio do novo regime cambial (FSP 2005).

Cumpre salientar, ainda, que a valorização realizada pela autoridade monetária chinesa foi bastante aquém daquela requerida por líderes do Congresso americano, que recomendavam uma valorização de $15 \%$ a $20 \%$ do RMB em relação ao dólar. Alguns analistas, como Goldstein e Lardy (2005: B2), chegavam a sugerir uma valorização de $20 \%$ a $25 \%$ do yuan. Tomando-se por base a afirmação de um porta-voz não-identificado do Bank's People of China dias depois da mudança do regime cambial, publicada originalmente no jornal "Diário do Povo" da China: "Flutuações cambiais expressivas terão grande impacto na estabilidade econômica e financeira da China e, por isso, não atendem aos interesses fundamentais da China." (FSP 2005b: B3)

Esta afirmação, juntamente com a análise da trajetória do câmbio desde a adoção do novo sistema até o início de 2007, que aponta uma valorização nominal de apenas cerca de $4,5 \%$ em relação ao dólar, reitera a orientação gradualista do governo Chinês em relação à nova realidade cambial.

Portanto, em vez de sinalizar uma ruptura da conduta estratégica da política cambial levada a cabo pelas autoridades econômicas chinesas especialmente desde 1994, que colocaria em risco o elevado superávit em transações corrente do balanço de pagamentos do país, o novo regime cambial serviu para a China estrategicamente acomodar os conflitos internacionais ocasionados por sua "diplomacia do yuan fraco", conforme sustentado por Cunha e Biancareli (2005), e assim aprofundar sua inserção externa diferenciada, em linha com o objetivo do governo chinês de tornar o país um importante ator no cenário internacional ${ }^{14}$. É por conta disso que Cunha e Biancareli (2005: 14) afirmam acertadamente que "a flexibilização do yuan aparece como um movimento tático da China em seu esforço estratégico de manter uma bem-sucedida modernização e crescimento econômico.”

14 De acordo com as mais recentes estimativas do FMI (2007), depois de ter crescido 10,6\% em 2006, a China deverá registrar um crescimento econômico de $10 \%$ em 2007 e 9,5\% em 2008. 
DE OLIVEIRA, G. O estado e a inserção ativa na economia: a estratégia de...

\section{China: de "ganso voador" a "global player"}

A modernização econômica implementada na China desde o final dos anos 1970 implicou uma mudança substantiva na composição do PIB do país, que passou a apresentar uma participação crescente da indústria e dos serviços em detrimento da agricultura, que por seu turno entre $1970-2000$ passou de $40 \%$ para $16 \%$ do PIB, conforme se pode observar a partir da Tabela 2. Não menos importante, a participação do emprego industrial no emprego total, que no início do período considerado era de $10 \%$, atingiu a marca de $23 \%$ em 2000 , movimento provocado pelo ritmo de crescimento mais acelerado da produção dos setores industrial e de serviços ante o setor agrícola (Figura 5).

TABELA 2- MUDANÇA DA ESTRUTURA DA ECONOMIA CHINESA (1970-2000)

\begin{tabular}{lccccccccccccc}
\hline $\begin{array}{l}\text { Investimento e } \\
\text { Financiamento }\end{array}$ & 1990 & 1991 & 1992 & 1993 & 1994 & 1995 & 1996 & 1997 & 1998 & 1999 & 2000 & 2001 & 2002 \\
Investimento & 100,0 & 100,0 & 100,0 & 100,0 & 100,0 & 100,0 & 100,0 & 100,0 & 100,0 & 100,0 & 100,0 & 100,0 & 100,0 \\
Estatal & 66,1 & 66,4 & 68,1 & 60,6 & 56,4 & 54,4 & 52,4 & 52,5 & 54,1 & 53,4 & 50,1 & 47,3 & 43,7 \\
Propriedade coletiva & 11,7 & 12,5 & 16,8 & 17,7 & 16,2 & 16,4 & 15,9 & 15,4 & 14,8 & 14,5 & 14,6 & 14,2 & 13,7 \\
Propriedade individual & 22,2 & 21,1 & 15,1 & 11,3 & 11,6 & 12,8 & 14,0 & 13,7 & 13,2 & 14,1 & 14,3 & 14,6 & 14,5 \\
Outros & - & - & - & 10,4 & 15,8 & 16,3 & 17,7 & 18,3 & 18,0 & 18,0 & 21,0 & 23,9 & 28,1 \\
Fontes de financiamento & 100,0 & 100,0 & 100,0 & 100,0 & 100,0 & 100,0 & 100,0 & 100,0 & 100,0 & 100,0 & 100,0 & 100,0 & 100,0 \\
Estatal & 8,7 & 6,8 & 4,3 & 3,7 & 3,0 & 3,0 & 2,7 & 2,8 & 4,2 & 6,2 & 6,4 & 6,7 & 7,0 \\
Empréstimos domésticos & 19,6 & 23,5 & 27,4 & 23,5 & 22,4 & 20,5 & 19,6 & 18,9 & 19,3 & 19,2 & 20,3 & 19,1 & 19,7 \\
Investimento estrangeiro & 6,3 & 5,7 & 5,8 & 7,3 & 9,9 & 11,2 & 11,8 & 10,6 & 9,1 & 6,7 & 5,1 & 4,6 & 4,6 \\
Outros & 65,4 & 64,0 & 62,5 & 65,5 & 64,7 & 65,3 & 66,0 & 67,7 & 67,4 & 67,8 & 68,2 & 69,7 & 68,7 \\
Investimento / PIB (em \%) & 24,4 & 25,9 & 30,3 & 37,7 & 36,4 & 34,4 & 33,8 & 33,8 & 33,8 & 33,8 & 33,8 & 38,2 & 41,2 \\
\hline
\end{tabular}

Fonte: World Bank (2003: 104).

Embora a renda per capta na China medida em dólares correntes, de US\$ 1.702 em 2005, seja muito inferior a dos países de renda média como o Brasil, de US\$ 4.315, quando medida sob a metodologia da paridade poder de compra o patamar da renda per capta alcança US\$ 7.204, patamar bastante próximo ao observado no Brasil sob o mesmo critério de cálculo, de US\$ 8.584. Portanto, considerando a renda em termos de poder de compra, as transformações econômicas ocorridas na China nas últimas três décadas atuaram no sentido de alçar o país à condição de uma nação de renda média, além de sinalizar para uma situação cada vez mais promissora. 
DE OLIVEIRA, G. O estado e a inserção ativa na economia: a estratégia de...

FIGURA 5- CRESCIMENTO DO PIB CHINÊS POR SETORES (1981-2005)

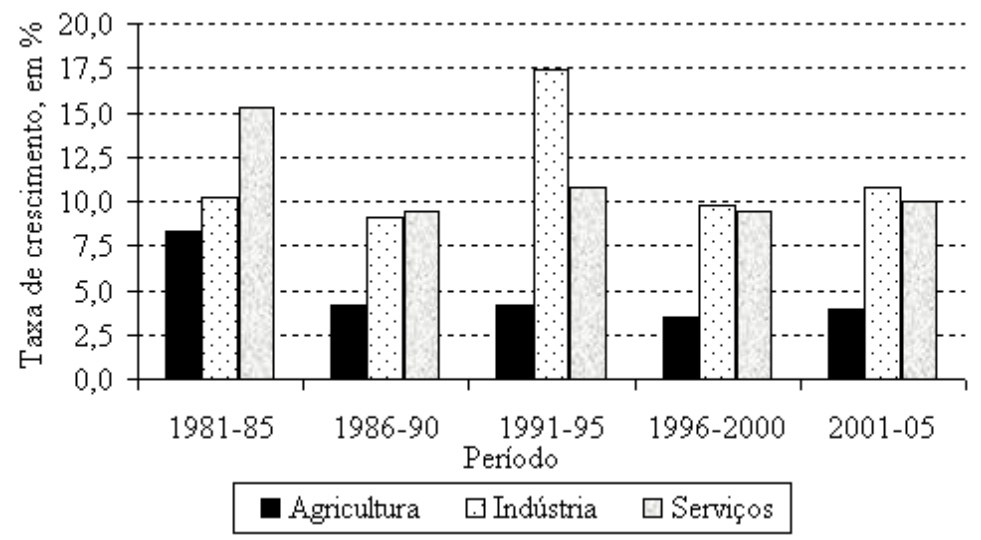

Fonte: World Bank (2007).

As reformas econômicas modernizantes conjugadas com uma política econômica pró-crescimento tem concorrido para configurar um ambiente macroeconômico estável, oferecendo níveis crescentes de retorno às empresas estatais e privadas (World Bank 2003). Este processo tem permitido à China migrar da condição de "ganso voador" para a de "global player". Como se pode verificar na Figura 6, notadamente desde a segunda metade da década de 1980 , a China tem apresentado um crescimento exponencial de seu comércio exterior, aumentando tanto as exportações, quanto as importações. Em 2005, a soma das exportações de bens e serviços em proporção do PIB alcançou US\$ 1,55 trilhão, o equivalente a $69 \%$ do PIB, marca somente inferior a dos EUA e da Alemanha.

FIGURA 6- EXPORTAÇÕES E IMPORTAÇÕES NA CHINA (1980-2005)

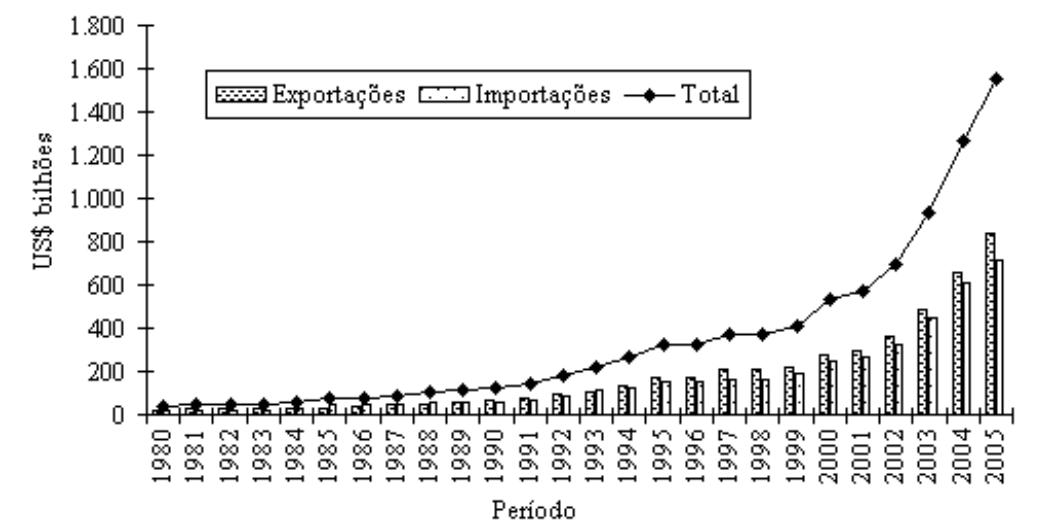

Fonte: World Bank (2007). 
DE OLIVEIRA, G. O estado e a inserção ativa na economia: a estratégia de...

Na Tabela 3, observa-se que as exportações de produtos manufaturados passaram de uma participação de $0,9 \%$ das exportações mundiais de manufaturados no interregno $1981-85$, para $6,2 \%$ no período 2001 03, ultrapassando o Reino Unido, 5,1\%, e aproximando-se da participação do Japão, de 8,1\%. Em 2005 os produtos industrializados

TABELA 3- EXPORTAÇÕES DE MANUFATURAS EM PROPORÇÃO DAS EXPORTAÇÕES MUNDIAIS DE PRODUTOS MANUFATURADOS - PAÍSES SELECIONADOS (1962-2003)

\begin{tabular}{|c|c|c|c|c|c|c|c|c|}
\hline \multirow[b]{2}{*}{ Período } & \multicolumn{2}{|c|}{ Estados Unidos } & \multicolumn{2}{|c|}{ Reino Unido } & \multicolumn{2}{|c|}{ Alemanha } & \multicolumn{2}{|c|}{ Japão } \\
\hline & $\begin{array}{c}\text { Manufatura } \\
\text { total }\end{array}$ & Têxtil & $\begin{array}{c}\text { Manufatura } \\
\text { total }\end{array}$ & Têxtil & $\begin{array}{c}\text { Manufatura } \\
\text { total }\end{array}$ & Têxtil & $\begin{array}{c}\text { Manufatura } \\
\text { total }\end{array}$ & Têxtil \\
\hline $1962-1965$ & 19,2 & 5,5 & 12,2 & 6,0 & 18,2 & 7,9 & 7,1 & 11,7 \\
\hline $1966-1970$ & 17,2 & 5,1 & 9,6 & 5,1 & 18,3 & 7,7 & 9,1 & 9,6 \\
\hline 1971-1975 & 14,4 & 3,1 & 7,8 & 4,3 & 19,3 & 8,0 & 11,1 & 4,1 \\
\hline $1976-1980$ & 13,8 & 3,4 & 7,6 & 5,2 & 17,8 & 8,7 & 12,2 & 1,9 \\
\hline 1981-1985 & 14,5 & 2,9 & 6,3 & 4,1 & 14,8 & 7,3 & 14,9 & 1,8 \\
\hline 1986-1990 & 11,9 & 2,3 & 6,1 & 3,0 & 15,5 & 6,9 & 13,5 & 0,9 \\
\hline 1991-1995 & 13,1 & 3,5 & 5,4 & 2,7 & 13,2 & 5,4 & 12,2 & 0,5 \\
\hline 1996-2000 & 13,3 & 4,6 & 5,3 & 2,5 & 10,8 & 4,2 & 9,4 & 0,3 \\
\hline \multirow[t]{2}{*}{ 2001-2003 } & 12,0 & 3,0 & 5,1 & 1,9 & 11,1 & 4,1 & 8,1 & 0,3 \\
\hline & \multicolumn{2}{|l|}{ Coréia } & \multicolumn{2}{|c|}{ Taiwan } & \multicolumn{2}{|c|}{ China } & & \\
\hline Período & $\begin{array}{l}\text { Manufatura } \\
\text { total }\end{array}$ & Têxtil & $\begin{array}{c}\text { Manufatura } \\
\text { total }\end{array}$ & Têxtil & $\begin{array}{l}\text { Manufature } \\
\text { total }\end{array}$ & Têxti & & \\
\hline $1962-1965$ & 0,1 & 0,3 & 0,2 & 0,5 & - & - & & \\
\hline $1966-1970$ & 0,2 & 2,5 & 0,4 & 2,1 & - & - & & \\
\hline 1971-1975 & 0,7 & 6,5 & 0,8 & 5,6 & - & - & & \\
\hline $1976-1980$ & 1,5 & 10,1 & - & - & - & - & & \\
\hline 1981-1985 & 2,3 & 11,2 & - & - & 0,9 & 5,5 & & \\
\hline $1986-1990$ & 2,7 & 9,9 & 2,8 & 4,4 & 1,5 & 7,8 & & \\
\hline 1991-1995 & 2,9 & 4,7 & 2,9 & 2,9 & 2,9 & 13,7 & & \\
\hline 1996-2000 & 3,0 & 2,6 & 2,8 & 1,8 & 3,9 & 16,5 & & \\
\hline 2001-2003 & 3,1 & 2,0 & 2,6 & 1,2 & 6,2 & 20,8 & & \\
\hline
\end{tabular}

Fonte: Unctad (2005a: 78). 
DE OLIVEIRA, G. O estado e a inserção ativa na economia: a estratégia de...

representavam 92\% das exportações de mercadorias na China, ante 54\% no Brasil e 70\% na Índia, com o setor de tecnologia da informação respondendo por cerca de $30 \%$ das vendas externas de mercadorias do país, o que sinaliza uma inserção diferenciada da China no fluxo de comércio internacional (FSP 2006; World Bank 2007). Em 2005 o grau de abertura externa da economia chinesa alcançava cerca de $69 \%$, contra $29 \%$ no Brasil e $45 \%$ na Índia, medida pela razão entre a soma das exportações e importações de bens e serviços e o PIB (Figura 7). Não menos importante, a participação das exportações de produtos de alta intensidade tecnológica no total das exportações de produtos manufaturados na China, que em 1992 alcançava patamar similar ao do Brasil, em torno de 6\%, em 2005 atingiu 30,60\%, contra 12,85\% no Brasil. Na Índia, a participação não alcançava 5\% em 2004 (Figura 8).

FIGURA 7- GRAU DE ABERTURA ECONÔMICA: CHINA, ÍNDIA E BRASIL (1980-2005)

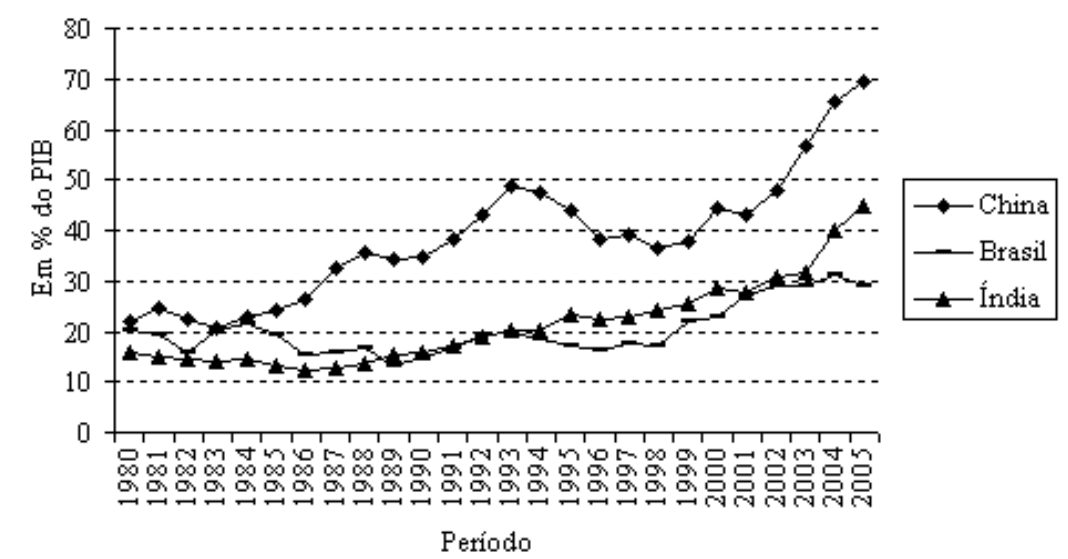

Fonte: World Bank (2007). Calculado a partir da divisão entre a soma das importações e exportações de bens e serviços pelo PIB do ano respectivo.

Mesmo admitindo que as principais empresas chinesas ainda se colocam em posição vulnerável frente às grandes empresas globais, vez que com uma participação ainda tímida em âmbito mundial, conforme sugerido por Nolan e Zang (2002:52), os dados apresentados elucidam a crescente importância do país no cenário econômico global, com ganhos crescentes de participação no comércio internacional. De acordo com Flassbeck (2005: 2):

a China tem também se tornado um importante jogador global num crescente número de indústrias. Como resultado, a China tem agora um poder significativo na política econômica internacional [tradução do autor] 
FIGURA 8- PARTICIPAÇÃO DOS PRODUTOS DE ALTA INTENSIDADE TECNOLÓGICA NAS EXPORTAÇÕES DE PRODUTOS MANUFATURADOS: CHINA, ÍNDIA E BRASIL (1980-2005)

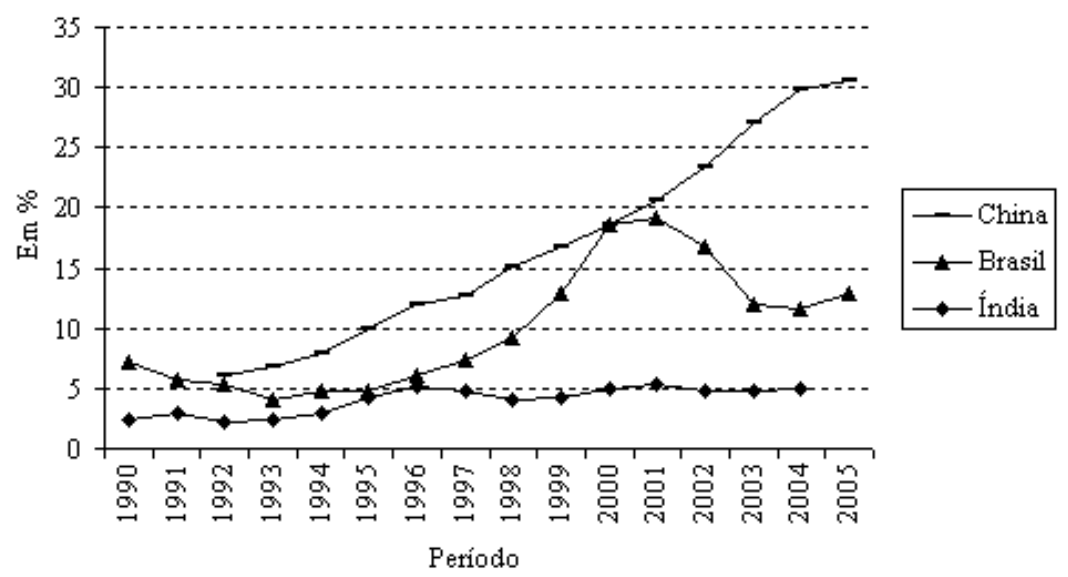

Fonte: World Bank (2007).

Fazendo uso de uma intensa política industrial para tornar as empresas competitivas internacionalmente, tal como observado nas economias do sudeste asiático, o Estado Chinês tem conseguido tornar as grandes empresas domésticas em grandes líderes globais, buscando percorrer a mesma trajetória de economias como Japão e Coréia. Com diferenciais importantes em relação aos países vizinhos, como uma estrutura industrial dual, a extrema habilidade de demandar e atrair transferência de tecnologia em larga escala e a estruturação de sistemas internos de inovação mediante estudo e aplicação ao nível nacional de tecnologias avançadas desenvolvidas em outros países, a China tem conseguido reduzir sua dependência de know-how estrangeiro a partir do desenvolvimento de propriedade intelectual controlada internamente (Linden 2004).

Com isto, a China tem diferenciado sua estrutura industrial daquela observada nos países vizinhos, especialmente Coréia e Taiwan, contemplando tanto um amplo grupo de pequenas empresas dinâmicas que exploram nichos lucrativos de mercado, amparadas por financiamento público e privado e por programas de incubadoras patrocinados pelo Estado, quanto grandes conglomerados empresariais, notadamente de propriedade estatal (Linden 2004). A este respeito, Linden (2004:3) afirma que:

A estrutura industrial é uma área importante na qual a China se distingue de seus vizinhos. O desenvolvimento em outros países da região tem sido levado ou por pequenas ou por grandes empresas, 
DE OLIVEIRA, G. O estado e a inserção ativa na economia: a estratégia de...

enquanto o desenvolvimento da China contempla uma estrutura industrial dual. [tradução do autor]

De acordo com Linden (2004), que realizou uma análise aprofundada da política industrial da China, a indústria de produtos eletrônicos, que tem contribuído mais fortemente para o crescimento dos países do Leste Asiático, tem ocupado papel central no crescimento econômico chinês. Em 2002, a produção de elétrico-eletrônicos na China, como discos de vídeo, televisão digital, circuitos integrados e telefonia celular, representou aproximadamente $3 \%$ do PIB, respondendo por $15 \%$ da produção mundial desses produtos. Neste sentido, a China tem utilizado um conjunto de instrumentos muito parecido com aquele utilizado pelas economias bem-sucedidas do Leste Asiático para desenvolver um padrão de alta competitividade das empresas, pautado na produção de produtos de alta intensidade tecnológica que decorre de um sistema interno de inovação (Linden 2004).

Deste modo, mediante o resgate de boa parte das políticas e instituições adotadas pelos países hoje desenvolvidos quando se achavam em processo de desenvolvimento, tomando-se por base a tese central de Chang (2004), a China tem se tornado um duplo pólo na economia mundial. Isto porque, conforme sustentado por Medeiros (2005): por um lado, o país tem se apresentado enquanto um exportador líquido de manufaturas intensivas em mão-de-obra para os EUA e o Japão, e, por outro, enquanto importador líquido para a Ásia, notadamente de máquinas e equipamentos, tecnologia e matérias-primas, condição que tem contribuído para a estruturação de um sistema interno de inovação. No que concerne a esse último aspecto, a inserção da China enquanto importante consumidor de matérias-primas tem implicado uma forte pressão altista sobre os preços das commodities em âmbito mundial, movimento que embora tenha inaugurado um componente inflacionário adicional especialmente nas economias desenvolvidas, tem atuado favoravelmente sobre as contas externas de países produtores de tais produtos, entre os quais o Brasil (World Bank 2006).

Há que se destacar, contudo, que se por um lado a demanda chinesa por matérias-primas tem pressionado para cima os preços das commodities, inaugurando um componente inflacionário nos países desenvolvidos, por outro a produção e a exportação de produtos manufaturados chineses a preços altamente competitivos tem exercido um importante impacto deflacionário na economia mundial. Este último movimento, cabe salientar, tem sobrepujado o primeiro, condição que tem contribuído de forma importante para a configuração de um cenário internacional marcado por baixos níveis de inflação e juros. Esta configuração, no entanto, tem sido assentada numa ordenação altamente frágil do 
sistema monetário internacional, mostrando-se muito mais enquanto subproduto de interesses comuns e circunstanciais particularmente entre os Estados Unidos e a China do que resultado de uma arquitetura financeira internacional subserviente aos propósitos da produção e do emprego (Oliveira et al. 2007). Isto porque: "O bloco industrializado da Ásia, sobretudo a China, funciona como uma engrenagem de transmissão entre a demanda gerada nos Estados Unidos e a oferta das economias 'exportadoras de recursos naturais"' (Belluzzo 2006: 33).

É importante notar que o sucesso econômico chinês observado nos últimos anos tem contato com uma participação ativa do Estado não apenas no provimento de um marco regulatório e um ambiente macroeconômico favoráveis, mas também e notadamente nas próprias decisões de investimento. Como se pode observar na Tabela 4, o investimento no país alcançou $41,2 \%$ do PIB em 2002, dos quais $43,7 \%$ corresponderam aos investimentos estatais, $14,5 \%$ das empresas individuais, $13,7 \%$ das empresas coletivas e $28,0 \%$ de outras fontes. Neste processo, ademais, tem se mostrado indispensável a contribuição do crédito, que respondeu por cerca de $20 \%$ das fontes de financiamento utilizadas para a compra de ativos fixos na maior parte do interregno 1990-2002, como mostrado na Tabela 4.

Já no que diz respeito ao âmbito fiscal, embora a forte presença do Estado chinês na economia esteja gerando um quadro de permanente déficit público nominal, na faixa dos $3 \%$ no interregno 2002-07, de acordo com as projeções do World Bank (2003), a dívida pública do país se encontra em nível altamente confortável, uma vez que inferior a 30\% do PIB, resultado da combinação de elevado ritmo de crescimento econômico com a prática de baixas taxas de juros básicas (Tabela 5).

Este comportamento altamente dinâmico da economia chinesa iniciado a partir do início dos anos 1980 tem permitido ao país importantes conquistas sociais, embora os desafios sejam ainda altamente significativos. Isto porque, se por um lado o crescimento econômico tem permitido a redução do nível de pobreza, o aumento do índice de Gini e uma forte mobilidade social da população localizada nas áreas urbanas, por outro tem-se observado um movimento de acentuação da desigualdade de renda intra-regional, com a renda média da população urbana crescendo sob ritmo superior a da população rural, e inter-regional, com as regiões costeiras apresentando um nível de renda cada vez mais superior ao das regiões do interior (World Bank 2003).

Com uma população rural em torno de $60 \%$, que corresponde a aproximadamente 760 milhões de pessoas, um dos grandes desafios da China no século XXI consiste na continuidade de um ritmo de crescimento econômico capaz de acomodar o intenso fluxo migratório das áreas 
DE OLIVEIRA, G. O estado e a inserção ativa na economia: a estratégia de...

TABELA 4- INVESTIMENTO E FONTES DE FINANCIAMENTO NA CHINA (1990-2002)

\begin{tabular}{|c|c|c|c|c|c|c|c|c|c|c|c|c|c|}
\hline $\begin{array}{l}\text { Investimento e } \\
\text { Financiamento }\end{array}$ & 1990 & 1991 & 1992 & 1993 & 1994 & 1995 & 1996 & 1997 & 1998 & 1999 & 2000 & 2001 & 2002 \\
\hline Investimento & 100,0 & 100,0 & 100,0 & 100,0 & 100,0 & 100,0 & 100,0 & 100,0 & 100,0 & 100,0 & 100,0 & 100,0 & 100,0 \\
\hline Estatal & 66,1 & 66,4 & 68,1 & 60,6 & 56,4 & 54,4 & 52,4 & 52,5 & 54,1 & 53,4 & 50,1 & 47,3 & 43,7 \\
\hline Propriedade coletiva & 11,7 & 12,5 & 16,8 & 17,7 & 16,2 & 16,4 & 15,9 & 15,4 & 14,8 & 14,5 & 14,6 & 14,2 & 13,7 \\
\hline Propriedade individual & 22,2 & 21,1 & 15,1 & 11,3 & 11,6 & 12,8 & 14,0 & 13,7 & 13,2 & 14,1 & 14,3 & 14,6 & 14,5 \\
\hline Outros & - & - & - & 10,4 & 15,8 & 16,3 & 17,7 & 18,3 & 18,0 & 18,0 & 21,0 & 23,9 & 28,1 \\
\hline Fontes de financiamento & 100,0 & 100,0 & 100,0 & 100,0 & 100,0 & 100,0 & 100,0 & 100,0 & 100,0 & 100,0 & 100,0 & 100,0 & 100,0 \\
\hline Estatal & 8,7 & 6,8 & 4,3 & 3,7 & 3,0 & 3,0 & 2,7 & 2,8 & 4,2 & 6,2 & 6,4 & 6,7 & 7,0 \\
\hline Empréstimos domésticos & 19,6 & 23,5 & 27,4 & 23,5 & 22,4 & 20,5 & 19,6 & 18,9 & 19,3 & 19,2 & 20,3 & 19,1 & 19,7 \\
\hline Investimento estrangeiro & 6,3 & 5,7 & 5,8 & 7,3 & 9,9 & 11,2 & 11,8 & 10,6 & 9,1 & 6,7 & 5,1 & 4,6 & 4,6 \\
\hline Outros & 65,4 & 64,0 & 62,5 & 65,5 & 64,7 & 65,3 & 66,0 & 67,7 & 67,4 & 67,8 & 68,2 & 69,7 & 68,7 \\
\hline Investimento / PIB (em \%) & 24,4 & 25,9 & 30,3 & 37,7 & 36,4 & 34,4 & 33,8 & 33,8 & 33,8 & 33,8 & 33,8 & 38,2 & 41,2 \\
\hline
\end{tabular}

Fonte: World Bank (2003: 128).

TABELA 5- FINANÇAS PÚBLICAS NA CHINA - ESTIMATIVAS (2002-07)

\begin{tabular}{lcccccc}
\hline Finanças & 2002 & 2003 & 2004 & 2005 & 2006 & 2007 \\
Públicas & 18,7 & 18,8 & 19,1 & 19,3 & 19,4 & 19,6 \\
Receita fiscal & 12,0 & 22,2 & 22,3 & 22,4 & 22,5 & 22,6 \\
Gasto fiscal & 22,6 & & & & & \\
$\begin{array}{l}\text { Resultado } \\
\text { Fiscal }\end{array}$ & $-3,3$ & $-3,4$ & $-3,2$ & $-3,1$ & $-3,1$ & $-3,0$ \\
Dívida pública & 26,3 & 27,4 & 28,3 & 29,1 & 29,5 & 29,7 \\
\hline
\end{tabular}

Fonte: World Bank (2003: 60).

rurais em direção às áreas urbanas ${ }^{15}$, que nos próximos anos alcançará cerca de 200 milhões de chineses, bem como na redução dos impactos do crescimento sobre a desigualdade inter e intra-regional gerada

contraditoriamente pelo próprio crescimento da renda nacional. Não menos importante, o rápido crescimento econômico chinês tem contado com relações de trabalho bastante precarizadas ${ }^{16}$, além de fontes energéticas altamente poluidoras. Das dez cidades mais poluídas do

15 De acordo com Duzert (2005), das 470 milhões de pessoas que ainda vivem na área rural da China, cerca de $75 \%$ situam-se abaixo da linha de pobreza.

16 Ainda segundo Duzert (2005), na China apenas 20\% da População Economicamente Ativa têm acesso à previdência social. 
mundo, oito são chinesas, o que tem implicado a morte de 300 mil pessoase a perda de 740 mil acres de floresta por ano no país. Todos estes fatores, assomados a outros de diferentes ordens, como desrespeito à propriedade intelectual, às patentes e aos direitos humanos, têm proporcionado ao país uma parcela de competitividade que pode ser caracterizada como "espúria", ante a impossibilidade de permanência sob uma perspectiva intertemporal, condição que potencia os desafios futuros para a continuidade do desenvolvimento econômico da China (Duzert 2005)

Contudo, embora os desafios sejam grandes, o Estado chinês tem mostrado bastante habilidade na adequação dos instrumentos de política econômica às circunstâncias de cada momento, a partir de uma orientação política ao mesmo tempo gradualista e pragmática. O sucesso econômico da China nos últimos anos ratifica a importância do papel do Estado no desenvolvimento das nações e mostra que o "capitalismo organizado" se traduz na melhor maneira de se enfrentar os desafios impostos pela globalização (Schwartz 2006).

Nestes termos, pode-se inclusive afirmar que a China tem conseguido administrar o atual padrão sistêmico de riqueza do capitalismo contemporâneo, tal qual sustentado por Braga (1997), a partir de um mix de política econômica que privilegia o lado real da economia ante o financeiro, convertendo as forças instabilizadoras endógenas ao sistema capitalista em forças propulsoras do crescimento da produção e do emprego.

\section{Conclusão}

Com a execução de uma política econômica considerada pouco convencional por instituições como FMI e Banco Mundial, a China registrou taxas de crescimento excepcionais nos últimos 25 anos. Uma característica marcante da política econômica chinesa tem sido a sua rápida adaptação às circunstâncias e exigências de cada momento, mas sem se dissociar da orientação política que a rege, pautada no desenvolvimento econômico.

O caso chinês revela a importância das políticas internas de desenvolvimento não apenas no processo de dinamização, mas também e notadamente de autonomização do ciclo de negócios da economia, cuja continuidade tende a permitir a superação da condição de subdesenvolvimento. Serve para contradizer, portanto, teses convencionais que sustentam a impossibilidade de os países da periferia empenharem políticas nacionais autônomas de desenvolvimento econômico e social sob contexto de globalização. 
DE OLIVEIRA, G. O estado e a inserção ativa na economia: a estratégia de...

A experiência chinesa tem ratificado a importância do papel do Estado no desenvolvimento das nações, mostrando que o "capitalismo administrado" se traduz na forma mais eficiente de se lidar com os desafios impostos pela globalização. Enquanto esta estratégia tem permitido à China superar progressivamente as barreiras impostas pela condição de subdesenvolvimento, viabilizando sua migração da condição de "ganso voador" para a de "global player", aos países da periferia que optaram pela agenda neoliberal tem restado apenas amargurar a acentuação da condição de "patos vulneráveis", nos termos utilizados por Palma (2005).

\section{Referências}

ACIOLY, Luciana (2005). "China: uma inserção externa diferenciada". Economia Política Internacional, CERI/IE/Unicamp, Campinas, n.7, pp. 24-31.

BELLUZZO, Luiz (2006). “As transformações da economia capitalista no pósguerra e a origem dos desequilíbrios globais". Política econômica em foco, Campinas, n.7, 24-41.

BRAGA, José (1997). "Financeirização global: o padrão sistêmico de riqueza do capitalismo contemporâneo". In TAVARES, M. \& FIORI, J. (Orgs). Poder e dinheiro: uma política de globalização. Petrópolis: Editora Vozes, pp. 195242.

CESARIN, Sergio (2005) "Ejes y estrategias del desarrollo económico chino: enfoques para América Latina y el Caribe". In CESARIN, S. \& MONETA, C. (orgs). China y America Latina: nuevos enfoques sobre cooperación y desarrollo. ¿ una segunda ruta de la seda? Buenos Aires: BIDINTAL, pp.3-48.

CHANG, Ha-Joon (2004). Chutando a escada: a estratégia do desenvolvimento em perspectiva histórica. São Paulo: Unesp.

CUNHA, A. \& BIANCARELI, A. \& PRATES, D. (2006). "A diplomacia do yuan: uma análise da estratégia de internacionalização financeira da China”. VII Reunión de Economía Mundial, Alicante.

CUNHA, A. \& BIANCARELI, A. (2005). "O novo regime cambial Chinês e a diplomacia do 'yuan fraco'”. Economia Política Internacional, CERI/IE/ Unicamp, Campinas, n.7, 12-23.

DUZERT, Yann (2005). "Desafios do milagre Chinês”. Valor Econômico, Opinião, A12.

FLASSBECK, H. (2005) “China's spectacular growth since the Mid-1990s Macroeconomic conditions and economic policy changes". In UNCTAD. China in a Globalizing World. New York: United Nations.

FSP - Folha de São Paulo (2005). "Banda será de 1,5\% para a maioria das moedas da cesta." Dinheiro, B5.

FSP - Folha de São Paulo (2005a). "CHINA cede a pressão e abandona câmbio 
fixo ." Dinheiro, B4.

FSP - Folha de São Paulo (2005b). "CHINA mostra gradualismo com novo câmbio". Dinheiro, B4.

FSP - Folha de São Paulo (2006). "COMÉRCIO e investimento estrangeiro impulsionam ascensão chinesa." Caderno Especial, 8-9.

FUNDO MONETÁRIO INTERNACIONAL (2007). World Economic Outlook Database. URL: http://www.imf.org. Acesso em: 10 de agosto de 2007.

GOLDSTEIN, M. \& LARDY, N. (2005). "China deveria valorizar mais o yuan”. Folha de São Paulo, Dinheiro, B2.

HE, Fan (2003). “A reforma econômica da China: estratégias, sucessos e desafios". In CADERNOS ADENAUER IV. Experiências asiáticas: modelo para o Brasil? Rio de Janeiro: Fundação Konrad Adenauer, pp.33-61.

HUSSAIN, Athar (1994). "The Chinese economic performance: an assessment". In DWYER, Denis. China: the next decades. New York: Longman Scientific \& Technical, pp. 11-30.

LINDEN, Greg (2004). "China standard time: a study in strategic industrial policy". Business and Politics, v.6, issue 3 .

MEDEIROS, C. A. (2005). A China como um duplo pólo na economia mundial e a decentralização da economia asiática. (Versão Preliminar).

MEDEIROS, C. A. (2004) "A economia política da internacionalização sob liderança dos EUA: Alemanha, Japão e China”. In FIORI, J. (Org). $O$ poder americano. Petrópolis, RJ: Ed. Vozes, pp. 139-178.

MEDEIROS, C. A. (1999a) "Economia e política do desenvolvimento recente da China". Revista de Economia Política 19(3, 75):92-112.

MEDEIROS, C. A. (1999b) “China entre os séculos XX e XXI”. In FIORI, José Luís (Org). Estados e moedas no desenvolvimento das nações. Petrópolis, RJ: Ed. Vozes, pp.351-378.

MEDEIROS, C. A. (1997). "Globalização e a inserção diferenciada da Ásia e da América Latina”. In TAVARES, M. \& FIORI, J. (Orgs). Poder e dinheiro: uma política de globalização. Petrópolis: Editora Vozes, pp. 279-346.

NOLAN, Peter \& ZHANG, Jin (2002). "The challenge of globalization for large chinese firms". Discussion Papers, UNCTAD, n.162.

OLIVEIRA, Carlos A. (2005). "Reformas econômicas na China". Economia Política Internacional, CERI/IE/Unicamp, Campinas, n.7, 12-23.

OLIVEIRA, Giuliano et al. (2007). "O Sistema de Bretton Woods e a dinâmica do Sistema Monetário Internacional contemporâneo”. Anais do VII Congresso Brasileiro de História Econômica, Aracaju.

PALMA, Gabriel (2005). “Gansos voadores e patos vulneráveis: a diferença da liderança do Japão e dos Estados Unidos, no desenvolvimento do Sudeste Asiático e da América Latina". In: FIORI, J. (Org). O poder americano. $2^{\mathrm{a}}$ ed. Petrópolis,RJ: Ed. Vozes, pp.393-454.

SCHWARTZ, Gilson (2006). "Projeto nacional separa Índia e China do Brasil”. Folha de São Paulo, Carderno Especial - A corrida dos emergentes, 2-3. 
DE OLIVEIRA, G. O estado e a inserção ativa na economia: a estratégia de...

SYDOW, Cristina (2004). A entrada da China na OMC: riscos e oportunidades. São Paulo: dissertação de mestrado, PUC/SP, Programa de Estudos PósGraduados em Ciências Sociais da Pontifícia Universidade Católica de São Paulo.

UNCTAD (2005a). Trade and development report 2005. New York and Geneva: United Nations.

UNCTAD (2005b). World investment report 2005: transnational corporations and the internationalization of $R \& D$. United Nations: New York and Geneva.

VIEIRA, Flávio (2006). "China: crescimento econômico de longo prazo". Revista de Economia Política 26(3).

WALLERSTEIN, Immanuel (1979). The capitalism world economy. Cambridge: Cambridge University Press, pp.1-36.

WOLFF, M. \& SOTO, A. (2005). "El proceso de reformas en China y la política exterior: de Deng Xiaoping a Hu Jintao". In CESARIN, S. \& MONETA, C. (orgs). China y America Latina: nuevos enfoques sobre cooperación y desarrollo. ¿ una segunda ruta de la seda? Buenos Aires: BID-INTAL, pp.4983 .

WORLD BANK (2003). China: promoting growth with equity. Washington, DC: World Bank.

WORLD BANK (2006). China quarterly update. Beijing: World Bank.

WORLD BANK (2007). World development indicators (WDI). Washington, DC: World Bank.

Recebido em: 21 de maio de 2007 Primeira resposta em: 27 de julho de 2007 Aceite em: 10 de setembro de 2007 